\title{
Assemblages of Giardia duodenalis Isolates from Dogs by Amplification and Restriction of tpi and $\beta$-Giardin Genes and Sequencing of SSU rDNA Gene
}

\author{
Leticia Eligio-Garcia, Cortés-Campos Adrian, Cano-Estrada Apolinar, Jiménez-Cardoso Enedina* \\ Laboratorio de Investigación en Parasitología, Children Hospital of México, \\ México D.F., México \\ Email: *Jimenezce@yahoo.com.mx
}

Received March 14, 2013; revised April 14, 2013; accepted May 14, 2013

Copyright (C) 2013 Leticia Eligio-Garcia et al. This is an open access article distributed under the Creative Commons Attribution License, which permits unrestricted use, distribution, and reproduction in any medium, provided the original work is properly cited.

\begin{abstract}
Giardia duodenalis exhibits seven assemblages (A-G) that are distributed in different hosts. The A and B assemblages are commonly found in humans and several mammals, while $\mathrm{C}$ and $\mathrm{D}$ assemblages are typically found in dogs. The purpose of this study was to determine the assemblage of Giardia duodenalis present in the stool samples of ten canines using an assay based on PCR amplification, restriction analysis, and sequencing of the small subunit ribosomal DNA (SSU-rDNA), $\beta$-giardin, and triosephosphate isomerase (tpi) genes in order to establish the similarities or differences between the assemblage obtained with each gene. The results indicated that all positive isolates belonged to assemblage A, and specifically to the sub-assemblage A-I. A comparison of the SSU-rDNA gene sequence revealed the presence of three subgroups of assemblage A. These findings highlight the importance of canine transmission of Giardia in Mexico and its genetic plasticity. They also establish a method for additional and more molecularly extensive epidemiological studies to improve sanitation and hygiene in the most affected areas.
\end{abstract}

Keywords: Giardia duodenalis; Genotyping; Zoonosis; tpi; $\beta$-Giardin; SSU rDNA

\section{Introduction}

Giardia duodenalis is considered to be one of the most common causes of protozoan diarrhea in both humans and animals worldwide. The parasite infects a high number of dogs, especially newborn and puppies, and can cause severe gastrointestinal damage. The bacterium is also considered a potential factor of zoonosis transmission [1].

A higher prevalence of Giardia is found in tropical and subtropical areas, where it affects up to $30 \%$ of the population. In Mexico, the prevalence has been reported to be between $10 \%$ and $55.3 \%$, depending on the socioeconomic conditions and whether it is an urban or rural area [2-4]. G. duodenalis is a cosmopolitan pathogen with a very wide host range, including humans, domestic animals, and wild animal species [5].

This microscopic parasite clings to the surface of the intestine and causes asymptomatic infections, or can induce symptoms including chronic diarrhea, weight loss, and malabsorption that can be severe in some cases. Vet-

${ }^{*}$ Corresponding author. erinary research documents suggest that $5 \%-10 \%$ of all dogs in North America have giardiasis at any given time [6]. Canine giardiasis prevalence is $10 \%$ in dogs receiving proper care, $36 \%-50 \%$ in puppies, and can reach $100 \%$ in kennel dogs where a high stocking density and poor hygiene results in an increased risk of infection $[7,8]$. In cats, the prevalence is much lower, where it is $<2.4 \%$ in developed countries and up to $22 \%$ in developing countries [9]. However, the lower prevalence in cats could be related with poor Giardia diagnosis [10].

There are at least seven major assemblages of Giardia, which are referred to as assemblages (A-G), including two (A and $\mathrm{B}$ ) that are known to infect humans $[11,12]$. Assemblages A and B differ from each other by as much as $20 \%$ at the DNA sequence level [13]. There is also evidence that genetic exchange has resulted in hybrids, or mixed types, based on assemblage-specific PCR of Giardia isolates from cases of human infection [14].

Although Giardia isolated from dogs typically belong to assemblages $\mathrm{C}$ or $\mathrm{D}$, assemblages $\mathrm{A}$ and $\mathrm{B}$ have been identified in dogs in regions of high endemicity [15]. In 
addition, assemblages $\mathrm{E}, \mathrm{F}$, and $\mathrm{G}$ have been isolated from pigs and other farm mammals [16], cats [17], and rodents, respectively.

The ability to genetically characterize Giardia strains isolated from clinical and animal samples will contribute to a greater understanding of the epidemiology and pathogenesis of Giardia infection and the relative contributions of distinct assemblages to the severity of clinical infection and zoonotic potential. Therefore, in this study we used small subunit ribosomal DNA (SSU-rDNA), $\beta$-giardin, and triosephosphate isomerase (tpi) genes as genetic markers for genotypic analysis of the intestinal protozoan. The aim of this study was to identify the assemblage of isolates of Giardia duodenalis from canine in order to identify differences with human isolates. We developed an assay for the characterization of Giardia genomic DNA extracted from ten canine stool samples based on Polymerase Chain Reaction (PCR) amplification and sequencing of the three genes mentioned above.

\section{Methods}

\subsection{Identification of Parasites}

In the urban area of Mexico City, ten fecal specimens were collected from dogs, which were labeled as " 1 dog" to " $10 \mathrm{dog}$ ", and identification of parasitic structures was made by serial Faust method coproparasitoscopic analysis. Fecal specimens were stained with Lugol's iodine [18] and examined by microscopy to detect cysts of Giardia duodenalis. Cysts were concentrated from dog feces by repeated washing in distilled water and stored at $4{ }^{\circ} \mathrm{C}$ until use. Two Giardia isolates from human fecal specimens were named 2B2 and 3B2, respectively. The Portland-I strain of Giardia served as a control that represented the sub-type assemblage AI.

\subsection{PCR Amplification and Genotyping}

DNA was extracted from fecal samples using the QIAamp DNA Stool Mini Kit (Qiagen Inc., Valencia, CA) according to the manufacturer's instructions. All DNA concentrations were determined using an Epoch spectrophotometer (Biotek, Winooski, VT). The SSU-rDNA gene, tpi gene (encoding triosephosphate isomerase), and the $\beta$-giardin gene were each amplified by PCR.

The $\beta$-giardin gene was amplified in two steps using nested-PCR [19]. The first round of PCR was conducted in a $25 \mu \mathrm{L}$ reaction containing 200 pmol of each primer (G7: 5' -AAGCCCGACGACCTCACCCGCACTGC-3' and G759: 5'-GAGGCCGCCCTGGATCTTCGAGACGAC-3'), $10 \mathrm{mM}$ Tris- $\mathrm{HCl}, 50 \mathrm{mM} \mathrm{KCl}, 1 \mathrm{mM} \mathrm{MgCl}$, $0.2 \mathrm{mM}$ dNTPs, $2.5 \mathrm{U}$ Taq DNA Polymerase (Roche; Mannheim, Germany), and 200 ng of genomic DNA. The reaction was performed in a Maxygen Thermal cycler
(Sidney, Australia) with 45 cycles of $95^{\circ} \mathrm{C}$ for $30 \mathrm{~s}, 65^{\circ} \mathrm{C}$ for $30 \mathrm{~s}$, and $72^{\circ} \mathrm{C}$ for $1 \mathrm{~min}$. The second round of PCR, using the product of the first reaction as template, was performed in a $50 \mu \mathrm{L}$ reaction with 200 pmol of each primer (F: 5'-GAACGAGATCGAGGTCCG-3'; R: 5'CTCGACGAGCTTCGTT-3'), $10 \mathrm{mM}$ Tris-HCl, $50 \mathrm{mM}$ $\mathrm{KCl}, 1 \mathrm{mM} \mathrm{MgCl} 2,0.2 \mathrm{mM}$ dNTPs, $2.5 \mathrm{U}$ of Taq DNA Polymerase and $3 \mu \mathrm{L}$ of template. Amplification was conducted with 35 cycles of $94^{\circ} \mathrm{C}$ for $30 \mathrm{~s}, 53^{\circ} \mathrm{C}$ for $30 \mathrm{~s}$, and $72^{\circ} \mathrm{C}$ for 1 minute.

The tpi gene was amplified by nested-PCR, in which the first round was a duplex reaction to amplify two fragments corresponding to assemblages A and B simultaneously using four primers (TPIAF 5'-CGAGACAAGTGTTGAGATGC-3', TPIAR 5'-GGTCAAGAGCTTACAACACG-3', TPIBF 5'-GTTGCTCCCTCCTTTGTGC-3', and TPIBR 5'-CTCTGCTCATTGGTCTCGC-3') as previously described $[20,21]$. PCR amplification was performed in a volume of $50 \mu \mathrm{L}$ with $500 \mathrm{ng}$ of DNA in 1X PCR buffer, $2 \mathrm{mM} \mathrm{MgCl} 2,0.25 \mathrm{mM}$ of dNTP, and 1 $\mathrm{U}$ of Taq DNA Polymerase (Roche; Mannheim, Germany). Amplification was conducted in a Maxygen Thermal cycler (Sidney, Australia) with 25 cycles of $94^{\circ} \mathrm{C}$ for $20 \mathrm{~s}, 50^{\circ} \mathrm{C}$ for $30 \mathrm{~s}$, and $72^{\circ} \mathrm{C}$ for $1 \mathrm{~min}$. The second round of PCR comprised two separate heminested PCRs to amplify internal fragments of $476 \mathrm{bp}$ and $140 \mathrm{bp}$ that corresponded to the A and B assemblages, respectively. To amplify assemblage A, primers TPIAR and TPIAIF: 5'-CCAAGAAGGCTAAGCGTGC-3' were used using 3 $\mu \mathrm{L}$ of the first round amplicon as the template in a $50 \mu \mathrm{L}$ volume reaction. The amplification step used 33 cycles of $94^{\circ} \mathrm{C}$ for $20 \mathrm{~s}, 56^{\circ} \mathrm{C}$ for $30 \mathrm{~s}$, and $72^{\circ} \mathrm{C}$ for $1 \mathrm{~min}$. Alternatively, the $140 \mathrm{bp}$ fragment corresponding to assemblage B was amplified with primers TPIBIF: 5'-GCACAGAACGTGTATCTGG-3' and TPI-BR. Amplification was performed under the same conditions used for assemblage $\mathrm{A}$, except that the $\mathrm{MgCl}_{2}$ concentration in the PCR mixture was $1.5 \mathrm{mM}$.

The amplicons generated by PCR of $\beta$-giardin and tpi genes were digested with restriction enzymes (Promega; $\mathrm{Wi}$, USA) for subtyping. The tpi gene amplicons were digested with restriction enzyme RsaI and the $\beta$-giardin gene amplicons were digested with HaeIII. The products of the restriction enzyme digestion were separated by $2 \%$ agarose gel electrophoresis using a 100 bp DNA ladder (Promega, Madison, WI, USA) as a size standard. The DNA was visualized by staining the gel with ethidium bromide.

For SSU-rDNA gene amplification, $500 \mathrm{ng}$ of DNA were amplified using primers P (5'-GGTGGATCCTGCCGGAGCG-3') and -A (5'-GCTCTCCGGAGTCGAAC-3'), which have been previously described [22]. The PCR was performed in a $25 \mu \mathrm{L}$ thin wall microtube by adding 1X PCR amplification buffer, $1.2 \mu \mathrm{M}$ of each 
dNTP, $0.5 \mathrm{ng}$ of each primer, $500 \mathrm{ng}$ of DNA template, and 1.5 U of Taq polymerase (Roche; Mannheim, Germany). The thermal cycler (Maxygen; Sidney, Australia) was programmed for 1 cycle at $97^{\circ} \mathrm{C}$ for $5 \mathrm{~min}$, followed by 35 cycles of $94^{\circ} \mathrm{C}$ for $1 \mathrm{~min}, 50^{\circ} \mathrm{C}$ for $1 \mathrm{~min}$, and $72^{\circ} \mathrm{C}$ for $3 \mathrm{~min}$. One cycle at $94^{\circ} \mathrm{C}$ for $5 \mathrm{~min}$ completed the reaction.

PCR products of SSU-rDNA gene were purified using a SV gel and PCR clean up system purification kit (Promega; Wi, USA). Sequencing of PCR products was performed at the Biotechnology Institute (UNAM, Mexico) using an ABI 377 automated DNA sequencer and appropriate primers to each amplicon. Phylogenetic and molecular evolutionary analyses of sequences were conducted using MEGA version 5 [23].

\section{Results}

\subsection{Identification of Parasites}

Giardia infection of dog stool samples was confirmed by coproparasitoscopic analysis. Cysts were observed by light microscopy on slides stained with lugol-iodine (Figure 1).

\subsection{PCR Amplification and Genotyping}

The results from agarose gel electrophoresis of amplification and restriction reactions are shown in Figures 2 and 3. PCR amplification of the $\beta$-giardin gene generated a 500 bp fragment in all cases. In addition, human and canine samples (Figure 2(a)) as well as the restriction digest using HAE III (Figure 2(b)) generated fragments between 50 and $480 \mathrm{bp}$.

A $500 \mathrm{bp}$ amplicon was generated for the PCR amplification of the tpi gene (Figure 3(a)) When the product was digested with the Rsa I restriction enzyme, a 480 bp product was generated in all analyzed cases (Figure 3(b)). Based on these results, all isolates belonged to assemblage AI.

Alignment of sequences of the SSU-rRNA gene and a phylogenetic tree demonstrated differences in the first 100 nucleotides (Figure 4). Assemblage A presented tree

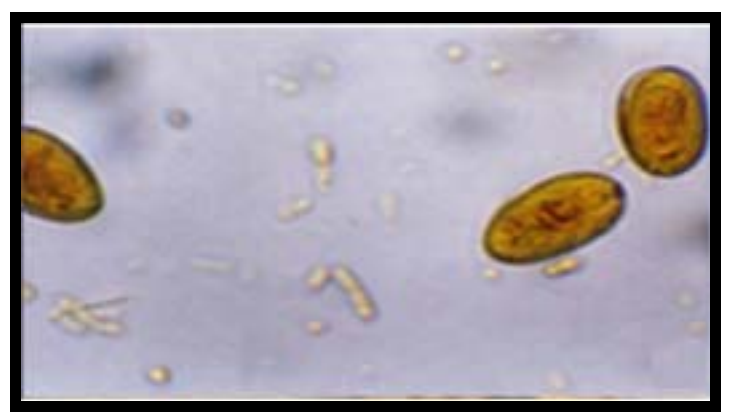

Figure 1. Cyst of Giardia duodenalis iodine stained in a canine sample, light microscopy 40×. (Olimpus BH2).

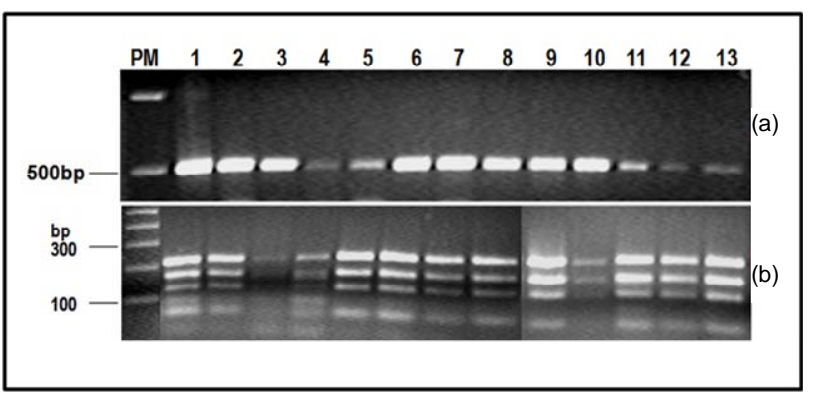

Figure 2. Genotyping by $\beta$-giardin-specific PCR (a) and restriction (b) analyzed by agarose gel electrophoresis. In (a), we can see the 500 bp corresponding to the amplicon and in (b), the fragments ranging from 100 to 200 bp corresponding to the $\mathrm{HaeII}$-digested $\beta$-giardin-specific nestedPCR product. PM) Molecular weight marker (100 and 500 bp ladder); 1) Portland-1 control; 2-11) Dog samples; 12) 2B2 and 13) 3B2.

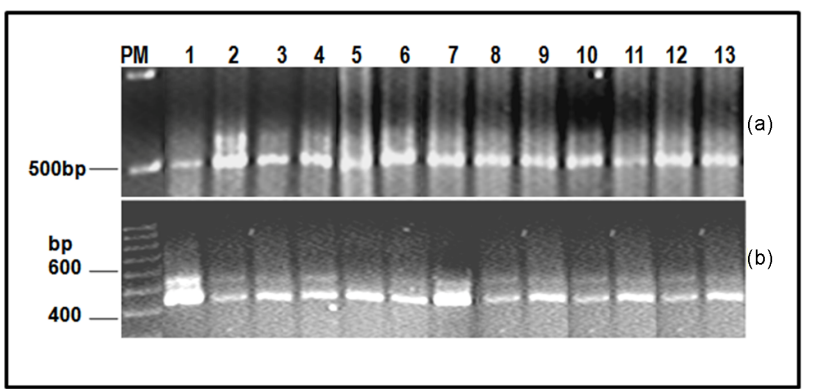

Figure 3. Genotyping by tpi-specific PCR (a) and restriction (b) analyzed by agarose gel electrophoresis. The fragment of $500 \mathrm{bp}$ corresponding to amplification of tpi gene and the 437 bp band corresponds to the $R$ saI-digested amplicon representative of assemblage A-I. PM) Molecular weight marker (100 and 500 bp ladder); 1) Portland-1 control; 2-11) Dog samples; 12) 2B2 and 13) 3B2.

subgroups A1, A2, and A3 with a clear isolate that was distinct from the others and presumably it could be $\mathrm{C}$ or $\mathrm{D}$ assemblage. The tree represents the genetic distance of the SSU rRNA gene between the isolates to make a classification of assemblage A in subgroups.

\section{Discussion}

The genotypic characterization of Giardia isolates from dogs using tpi, $\beta$-giardin and SSU ribosomal genes, demonstrated that the zoonotic assemblage A was found in samples obtained from canine, which was not different that those from human isolates. This finding suggests that there is a potential risk of $G$. duodenalis transmission from pet dogs to humans, although a study from a Taiwanese population showed that the risk of acquiring giardiasis from drinking infected water with viable cysts was greater than cohabitating with puppies [24]. Nevertheless, pet owners are encouraged to take appropriate hygiene measures to prevent and control the parasitic infection in this region. 


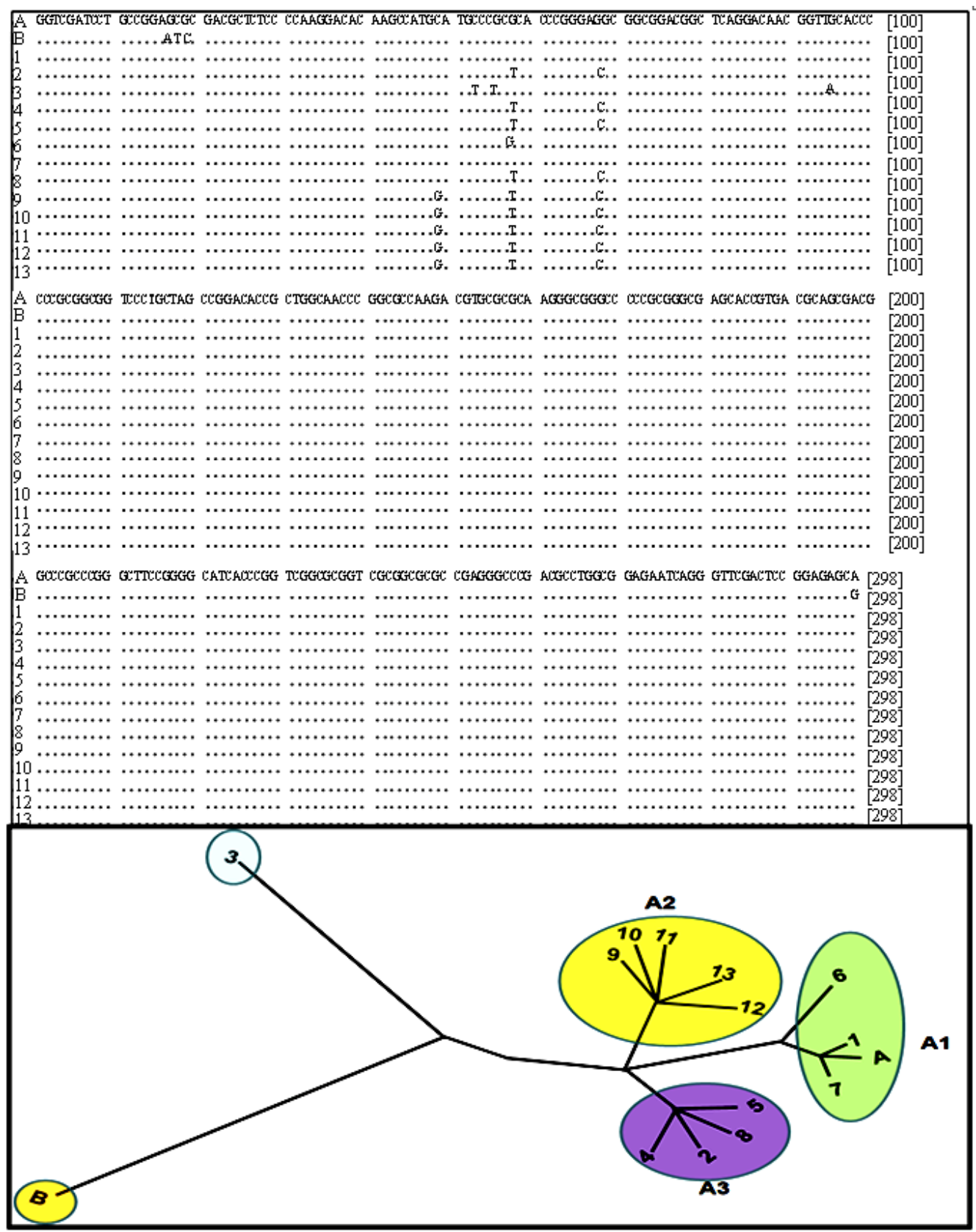

Figure 4. Sequence alignment of SSU rDNA gene amplification and phylogenetic tree building. A and B corresponding to sequence reported in genebank for assemblage $A$ and $B$ respectively, 1) Portland-1 control; 2-11) Dog samples; 12) $2 B 2$ and 13) 3B2. Phylogenetic and molecular evolutionary analyses of sequences were conducted using MEGA version 5.

The predominance of assemblage A most likely reflects the mechanism that led to infection of the animals based on the location where the fecal samples originated. The dogs may have consumed water that had been contaminated by livestock rather than by humans, which has important epidemiological ramifications. Genotyping studies have identified $G$. duodenalis isolates from dogs, some of which were found to be genetically identical to those obtained from humans [25]. Other studies have found that canine isolates from Canada predominantly belong to assemblages C, D, and G [26], while assemblages $\mathrm{C}$ and $\mathrm{D}$ were the most common in canine isolates from Asia and Europe [27,28].

Giardia duodenalis cysts obtained from dogs are morphologically indistinguishable from those obtained from human, and therefore it is necessary to determine the assemblage of each sample in order to detect crosstransmission between hosts. The cysts seen in Figure 1 correspond to canine samples, and visually they cannot be differentiated from cysts obtained from human sam- 
ples. It is known that human giardiasis is caused by two genetically distinct assemblages (A and B) of G. duodenalis, and a number of molecular assays have been developed for their specific detection in stool and environmental samples [29].

Phylogenetic analyses of ssU-rDNA sequences showed that all isolates belonged to assemblage $\mathrm{A}$, which separated into subgroups A1, A2, and A3. Therefore, the restriction digest enable us to identify the presence of distinct subgroups.

We have developed a method to detect Giardia based on the PCR amplification of three genes (SSU-rDNA, $\beta$-giardin, and tpi) based on prior genotyping studies. These genes were chosen because previous studies have found that they are the most consistent genes for genotyping [30]. Although DNA-based methods reported in the literature have been successfully used to make a classification of Giardia isolates, we did not observe differences among the genes analyzed from samples used in this study. Previous studies have detected frequent mismatches, intra-assemblage discordances, and mixed positions in tpi and $\beta$-giardin sequences, especially in assemblage B [31].

All fecal samples analyzed in this report (10 from dog and 2 from human) were determined to belong to the sub-type A-I assemblage. Nevertheless, based on the ribosomal gene sequences, we were able to detect differences in the isolates and classify assemblage A into subgroups $\mathrm{A} 1, \mathrm{~A} 2$, and $\mathrm{A} 3$, based on results previously reported [32]. The multiple alignment of amplified sequences of ribosomal gene allow us divide the isolates of group A into subgroups A1, A2 and A3 according with changes in the nucleotide sequences, this fact demonstrates the genome plasticity of Giardia and therefore its ability to adapt to different hosts promoting the transmission of giardiasis from animals to humans and vice versa.

\section{REFERENCES}

[1] R. D. Adam, "Biology of Giardia lamblia," Clinical Microbiology Review, Vol. 14, No. 3, 2001, pp. 447-475. doi:10.1128/CMR.14.3.447-475.2001

[2] R. Cedillo-Rivera, Y. A. Leal, L. Yepez-Mulia, A. GomezDelgado, G. Ortega-Pierres, R. Tapia-Conyer and O. Muñoz, "Seroepidemiology of Giardiasis in Mexico," American Journal of Tropical Medicine and Hygiene, Vol. 80, No. 1, 2009, pp. 6-10.

[3] M. Gamboa, J. Basualdo, M. Cordoba, B. Pezzani, M. Minvielle and H. Lahitte, "Distribution of Intestinal Parasitoses in Relation to Environmental and Sociocultural Parameters in La Plata, Argentina," Journal of Helminthology, Vol. 77, No. 1, 2003, pp. 15-20. doi: $10.1079 / \mathrm{JOH} 2002142$

[4] G. L. Paniagua, E. Monroy, O. Garcia-Gonzalez, J. Alonso, E. Negrete and S. Vaca, "Two or More Enteropathogens Are Associated with Diarrhoea in Mexican Chil- dren," Annals of Clinical Microbiology and Antimicrobials, Vol. 28, No. 1, 2007, pp. 6-17.

[5] R. C. Thompson, J. A. Reynoldson and A. H. Mendis, "Giardia and Giardiasis," Advances in Parasitology, Vol. 32, No. 1, 1993, pp. 71-160. doi:10.1016/S0065-308X(08)60207-9

[6] V. Mircean, A. Györke and V. Cozma, "Prevalence and Risk Factors of Giardia duodenalis in Dogs from Romania," Veterinary Parasitology, Vol. 184, No. 2-4, 2012, pp. 325-329. doi:10.1016/j.vetpar.2011.08.022

[7] E. Jiménez-Cardoso, L. Eligio-García, A. Cortes-Campos, A. Cano-Estrada, M. Pinto-Sagahon and C. NogueraEstrada, "The Frequency of Intestinal Parasites in Puppies from Mexican Kennels," Health, Vol. 2, No. 11, 2010, pp. 1317-1320. doi:10.4236/health.2010.211196

[8] C. S. Barr and D. D. Bowman, "Giardiasis," Selections Veterinary, Vol. 3, No. 1, 1995, pp. 43-48.

[9] R. Shukla, P. Giraldo, A. Kraliz, M. Finnigan and A. L. Sanchez, "Cryptosporidium spp. and Other Zoonotic Enteric Parasites in a Sample of Domestic Dogs and Cats in the Niagara Region of Ontario, Can," Veterinary Journal, Vol. 47, No. 1, 2006, pp. 1179-1184.

[10] J. López, K. Abarca, P. Paredes and E. Inzunza, "Intestinal Parasites in Dogs and Cats with Gastrointestinal Symptoms in Santiago, Chile," Revista Medica Chilena, Vol. 134, No. 1, 2006, pp. 193-200.

[11] M. Lalle, E. Jimenez-Cardosa, S. M. Cacciò and E. Pozio, "Genotyping of Giardia duodenalis from Humans and Dogs from Mexico Using a Beta-Giardin Nested Polymerase Chain Reaction Assay," Journal of Parasitology, Vol. 91, No. 1, 2005, pp. 203-205. doi:10.1645/GE-293R

[12] C. N. Macpherson, "Human Behaviour and the Epidemiology of Parasitic Zoonoses," International Journal for Parasitology, Vol. 35, No. 11-12, 2005, pp. 1319-1331. doi:10.1016/j.ijpara.2005.06.004

[13] S. M. Cacciò and U. Ryan, "Molecular Epidemiology of Giardiasis," Molecular and Biochemical Parasitology, Vol. 160, No. 2, 2008, pp. 75-80. doi:10.1016/j.molbiopara.2008.04.006

[14] P. T. Monis, R. H. Andrews, G. Mayrhofer and P. L. Ey, "Molecular Systematics of the Parasitic Protozoan Giardia intestinalis," Molecular Biology and Evolution, Vol. 16, No. 9, 1999, pp. 1135-1144. doi:10.1093/oxfordjournals.molbev.a026204

[15] M. A. Cooper, C. R. Sterling, R. H. Gilman, V. Cama, Y. Ortega and R. D. Adam, "Molecular Analysis of Household Transmission of Giardia lamblia in a Region of High Endemicity in Peru," The Journal of Infectious Diseases, Vol. 202, No. 11, 2010, pp. 1713-1721. doi: $10.1086 / 657142$

[16] J. Jerlström-Hultqvist, O. Franzén, J. Ankarklev, F. Xu, E. Nohýnková, J. O. Andersson, S. G. Svärd and B. Andersson, "Genome Analysis and Comparative Genomics of a Giardia intestinalis Assemblage E Isolate," $B M C$ Genomics, Vol. 11, No. 1, 2010, p. 543. doi:10.1186/1471-2164-11-543

[17] L. R. Ballweber, L. Xiao, D. D. Bowman, G. Kahn and V. A. Cama, "Giardiasis in Dogs and Cats: Update on Epi- 
demiology and Public Health Significance," Trends in Parasitology, Vol. 26, No. 4, 2010, pp. 180-189. doi:10.1016/j.pt.2010.02.005

[18] E. C. Faust, J. S. D'antonio, V. Odom, M. J. Miller, C. Peres, W. Sawitz, L. F. Thomen, J. Tobie and J. H. Walker, "A Critical Study of Clinical Laboratory Techniques for the Diagnosis of the Protozoan Cysts and Helminthes Egg in Feces," American Journal of Tropical Medicine and Hygiene, Vol. 18, No. 1, 1938, pp. 169-183.

[19] M. Lalle, E. Pozio, G. Capelli, F. Bruschi, D. Crotti and S. M. Cacciò, "Genetic Heterogeneity at the Beta-Giardin Locus among Human and Animal Isolates of Giardia duodenalis and Identification of Potentially Zoonotic Subgenotypes," International Journal of Parasitology, Vol. 35, No. 2, 2005, pp. 207-213. doi:10.1016/j.ijpara.2004.10.022

[20] C. F. Amar, P. H. Dear and J. McLauchlin, "Detection and Genotyping by Real-Time PCR/RFLP Analyses of Giardia duodenalis from Human Feces," Journal of Medical Microbiology, Vol. 52, No. 1, 2003, pp. 681-683. doi:10.1099/jmm.0.05193-0

[21] N. Molina, D. Polverino, M. Minvielle and J. Basualdo, "PCR Amplification of Triosephosphate Isomerase Gene of Giardia lamblia in Formalin-Fixed Feces," Revista Latinoamericana de Microbiologia, Vol. 49, No. 1-2, 2007, pp. 6-11.

[22] H. van Keulen, P. T. Macechko, S. Wade, S. Schaaf, P. M. Wallis and S. L. Erlandsen, "Presence of Human Giardia in Domestic, Farm and Wild Animals, and Environmental Samples Suggests a Zoonotic Potential for Giardiasis," Veterinary and Parasitology, Vol. 108, No. 2, 2002, pp. 97-107. doi:10.1016/S0304-4017(02)00181-4

[23] K. Tamura, D. Peterson, N. Peterson, G. Stecher, M. Nei and S. Kumar, "MEGA5: Molecular Evolutionary Genetics Analysis Using Maximum Likelihood, Evolutionary Distance, and Maximum Parsimony Methods," Molecular Biology and Evolution, Vol. 28, No. 1, 2011, pp. 27312739. doi: $10.1093 / \mathrm{molbev} / \mathrm{msr} 121$

[24] C. H. Liang, J. C. Tsaihong, Y. Y. Cheng and S. Y. Peng, "Occurrence and Genotype of Giardia Cysts Isolated from Faecal Samples of Children and Dogs and from Drinking Water Samples in an Aboriginal Area of Central Taiwan," Experimental Parasitology, Vol. 131, No. 2, 2012, pp. 204-209. doi:10.1016/j.exppara.2012.04.002

[25] R. Beck, H. Sprong, E. Pozio and S. M. Cacciò, "Genotyping Giardia duodenalis Isolates from Dogs: Lessons from a Multilocus Sequence Typing Study," Zoonotic Diseases, Vol. 12, No. 3, 2012, pp. 206-213. doi:10.1089/vbz.2011.0751

[26] R. M. McDowall, A. S. Peregrine, E. K. Leonard, C. Lacombe, M. Lake, A. R. Rebelo and H. Y. Cai, "Evaluation of the Zoonotic Potential of Giardia duodenalis in Fecal Samples from Dogs and Cats in Ontario. Can," Veterinary Journal, Vol. 52, No. 12, 2012, pp. 1329-1333.

[27] F. Berrilli, R. D’Alfonso, A. Giangaspero, M. Marangi, O. Brandonisio, Y. Kaboré, C. Glé, C. Cianfanelli, R. Lauro and D. Di Cave, "Giardia duodenalis Genotypes and Cryptosporidium Species in Humans and Domestic Animals in Côte d'Ivoire: Occurrence and Evidence for Environmental Contamination," Transactions of the Royal Society Tropical Medicine and Hygiene, Vol. 106, No. 3, 2012, pp. 191-195. doi:10.1016/j.trstmh.2011.12.005

[28] J. Li, P. Zhang, P. Wang, M. Alsarakibi, H. Zhu, Y. Liu, X. Meng, J. Li, J. Guo and G. Li, "Genotype Identification and Prevalence of Giardia duodenalis in Pet Dogs of Guangzhou, Southern China," Veterinary Parasitology, Vol. 188, No. 3-4, 2012, pp. 368-371.

[29] S. M. Cacciò, M. De Giacomo and E. Pozio, "Sequence Analysis of the Beta-Giardin Gene and Development of a Polymerase Chain Reaction-Restriction Fragment Length Polymorphism Assay to Genotype Giardia duodenalis Cysts from Human Faecal Samples," International Journal of Parasitology, Vol. 32, No. 1, 2002, pp. 1023-1030. doi:10.1016/S0020-7519(02)00068-1

[30] J. Bonhomme, L. Le Goff, V. Lemée, G. Gargala, J. J. Ballet and L. Favennec, "Limitations of tpi and $\beta$-Giardin Genes Sub-Genotyping for Characterization of Human Giardia duodenalis Isolates," Parasitology International, Vol. 60, No. 3, 2011, pp. 327-330. doi:10.1016/j.parint.2011.05.004

[31] A. V. Scorza, L. R. Ballweber, S. Tangtrongsup, C. Panuska and M. R. Lappin, "Comparisons of Mammalian Giardia duodenalis Assemblages Based on the $\beta$-Giardin, Glutamate Dehydrogenase and Triosephosphate Isomerase Genes," Veterinary and Parasitology, Vol. 189, No. 2-4, 2012, pp. 182-188. doi:10.1016/j.vetpar.2012.04.032

[32] L. Eligio-García, A. Cortes-Campos and E. Jiménez-Cardoso, "Genotype of Giardia intestinalis Isolates from Children and Dogs and Its Relationship to Host Origin," $\mathrm{Pa}$ rasitology Research, Vol. 97, No. 1, 2005, pp. 1-6. doi:10.1007/s00436-005-1368-9 